\title{
Kamu Diplomasisi Aracı Olarak Medya: TRT World Örneği*
}

\author{
Fatih Baritci (Arş. Gör.) \\ Selçuk Üniversitesi İletişim Fakültesi \\ fatihbaritci@hotmail.com \\ Orcid: 0000-0002-1283-821X \\ Hediyetullah Aydeniz (Doç. Dr.) \\ Marmara Üniversitesi İletişim Fakültesi \\ haydeniz@marmara.edu.tr \\ Orcid: 0000-0003-4481-632X
}

Başvuru Tarihi: 07.01.2019

Yayına Kabul Tarihi: 29.03.2019

Yayınlanma Tarihi: 22.07.2019

DOI: 10.17680/erciyesiletisim.509054

Baritci, F. ve Aydeniz, H. (2019). Kamu Diplomasisi Aracı Olarak Medya: TRT World Örneği. Erciyes İletişim Dergisi, 6 (2), 1551-1576. DOI: 10.17680/erciyesiletisim.509054

\section{Öz}

Soğuk Savaş dönemi kavramı olan kamu diplomasisi, uluslararası ilişkilerin bir faaliyet alanı ve iletişim süreç yönetimi olarak tanımlanmaktadır. Bir hükümetin ulusal amaçlarının ve güncel politikalarının olduğu kadar ulusunun fikir ve ideallerinin, kuruluşlarının ve kültürünün muhatap ülkelerin halkınca anlaşılması amacıyla bilgilendirilmesi ve o halkların ulusal menfaat çerçevesinde dış politikalara dâhil edilmesi amacıyla gerçekleștirilen iletişim sürecidir. Medya bu iletişim sürecinin yönetilmesindeki en önemli araçlardan birisidir. Hızlı, kolay ve etkin bir şekilde muhataplara ulaşabilme kabiliyeti bakımından medya, kamu diplomasisi aracı olarak kullanılmaktadır. Ayrıca internetin yaygınlaşması ve sektörel işleyiş bakımından medyanın bundan yararlanmasıyla medya türleri arasında dâhil edilen "yeni medya", basılı, işitsel ve görsel medyayı kapsayan geleneksel medyanın işleyişi açısından da kamu diplomasisi ile ilgili çalışma ve tartışmalar noktasında önemli bir role ve etkiye sahip olmuştur. Bu çalışmada 2015 yılında yayına başlayan ve TRT'nin İngilizce olarak dünyaya yayın yapan ilk kanalı olan TRT World, yeni medya da dikkate alınarak, bir yöntem olarak da kabul edilen tarihsel sosyolojik yaklaşımdan yararlanılarak Türkiye'nin kamu diplomasisi faaliyetleri kapsamında ele alınmaktadır. Kamu Diplomasisi Koordinatörlügü'nün çalışmalarından hareketle tespit edilmeye çalışılan Türkiye'nin kamu diplomasisi stratejisi ve bunun bir parçası olarak değerlendirilen TRT World, nitel yöntemlerden birisi olan vaka incelemesi/durum çalışması (case study) çerçevesinde ele alınmıștır. Bu çerçevede çoklu veri kaynaklarından ve veri toplama tekniklerinden yararlanılarak (istatistikler, yarı yapılandırılmış görüşme, dökümün incelemeleri, röportajlar, vb.) TRT World'un "kuruluş süreci, amaç ve hedefleri, bütçesi, organizasyonel yapısı, personel politikası, hedef kitlesi, konumlandırılması, haber stratejisi, TV programları, resmi web sayfası ve sosyal medya hesapları" incelenmiştir. Sonuç olarak TRT World'un dünyaya İngilizce yayın yaparak Türkiye'nin kamu diplomasisi stratejisinin unsurlarından birisi olduğu ve Türkiye'nin uluslararası yayıncılık çabalarının tamamlayıcı bir aktörü olduğu sonucuna varılmıştır.

Anahtar Kelimeler: Kamu Diplomasisi, Türkiye'nin Kamu Diplomasisi Stratejisi, Medya, TRT World.

\footnotetext{
* Bu çalışma, Marmara Üniversitesi Sosyal Bilimler Enstitüsü'ne 2018 yılında sunulan “Kamu Diplomasisi Aracı Olarak Medya: TRT World Örneği” başı|kıı Yüksek Lisans tezinden türetilmiş makaledir.
} 
Dissertation

\title{
The Media as Public Diplomacy Tool: The Case of TRT World
}

\author{
Fatih Baritci (Res. Asst) \\ Selçuk University Faculty of Communication \\ fatihbaritci@hotmail.com \\ Orcid: 0000-0002-1283-821X \\ Hediyetullah Aydeniz (Assoc. Prof. Dr.) \\ Marmara University Faculty of Communication \\ haydeniz@marmara.edu.tr \\ Orcid: 0000-0003-4481-632X
}

Date Received: 07.01.2019

Date Accepted: 29.03.2019

Date Published: 22.07.2019

DOI: 10.17680/erciyesiletisim.509054

\begin{abstract}
Public diplomacy, the concept of the Cold War period, is defined as an area of activity of international relations and communication process management. It is the communication process that carried out in order to inform the people of respondent countries about the national goals and current policies of a government as well as the nation's ideas and ideals, institutions and culture and to include those people in foreign policies on the purpose of national interest. Media is one of the important tool in managing this communication process. The media is used as a tool of public diplomacy in terms of its ability to reach its respondents quickly, easily and effectively. In addition, the new media, which has been included among media types due to the widespread use of the internet and the media benefiting from this in the terms of sectoral functioning, has also had an important role and effect at the point of the works and debates on public diplomacy in terms of the functioning of traditional media, which includes printed, audio and visual media. In this study, TRT World, which has started to broadcast in 2015 and the first channel of TRT to broadcast to all world in English, is addressed within the scope of public diplomacy events by considering the new media and benefiting from the historical sociological approach accepted as a method. Turkey's public diplomacy strategy, that tried to determine based on the works of The Office of Public Diplomacy, and TRT World, which is considered as a part of it, were addressed within the scope of the case study which is one of the qualitative research methods. In this context, TRT World's establishment process, goals and objectives, budget, organizational structure, personnel policy, audience, positioning, news strategy, TV programs, official web page and social media accounts were examined by using multiple data sources and data collection techniques (statistics, semi-structured interviews, podcasts, interviews, etc.). As a result, it is concluded that TRT World is one of the dimension of Turkish public diplomacy by broadcasting in English to the world and an integral actor of international broadcasting efforts in Turkey.
\end{abstract}

Keywords: Public Diplomacy, Turkey's Public Diplomacy Strategy, The Mass Media, TRT World. 


\section{Giriş}

Türkiye'de medya tarihinin başlangıcı ile modernleşme deneyimi arasında doğrudan bir paralellik vardır. Yaşanan güç ve toprak kaybını önlemek üzere devletin yeniden yapılandırılması olarak ifade edebileceğimiz Osmanlı modernleşmesi sürecinde medyanın önemli bir araç olarak görüldügü söylenebilir (Budak, 2014: 203). Bu bağlamda kamu yayıncılığına da modernleşme noktasında Batılı ülkelerle kurulan ilişki çerçevesinde her dönemde görevler ve sorumluluklar yüklenmiștir. Bütün bu çabaların merkezinde "development" kavramıyla ifadesini bulan kalkınma, gelişme ve medeni milletlerin seviyesine ve hatta muassır medeniyetlerin üstüne çıkma hedefi olmuştur. Modernleşme tecrübemizin de yapısal karakterini yansıtan bu anlayış doğal olarak öncelikle medyanın varlık bulması ve büyümesinde de en önemli saik olarak belirleyici olurken medya ve iletişim çalışmalarının da merkezinde yer almıştır (Bkz. Aydeniz, 2015). $\mathrm{Bu}$ çerçevede Türkiye'nin dünyada olup bitenleri bilme ve kendisini dünyaya anlatma ihtiyacını, aynı zamanda Fransızca olarak da yayımlanan ilk Türkçe gazetelerin mukaddimelerinde başlamak üzere Anadolu Ajansı'nın kuruluşunda da TRT’nin kuruluş sürecinde de görmek mümkündür. Gerek Osmanlı'nın gerekse de Türkiye'nin medyayla ve uluslararası yayıncılıkla yapmak istedikleri bugün kamu diplomasisine karşılık gelen girişimler olarak görülebilir. Kamu diplomasisi kavramının sahip olduğu anlam çerçevesi dikkate alındığında başlangıcından bu yana Türkiye'nin medya ile kurduğu ilişki kamu diplomasisi faaliyetleri çerçevesinde değerlendirilebilir.

Uluslararası yayıncılığın başlamasıyla daha çok gündeme gelen kamu diplomasisi temelde ülkelerin çıkarları doğrultusunda diğer ülkelerin kamuoylarını etkilemeyi amaçlamaktadır. Bu amaç doğrultusunda da devletler sahip oldukları yumuşak güç (soft power) araçlarından faydalanmaktadır. Devletlerin kendi çıkarlarına ulaşmak için sert güç (hard power) yerine yumuşak güç araçlarından faydalanmaları, yaptıkları icraatların dünya kamuoyunda meşru bir zemine oturmasını sağlamaktadır (Nye, 2004, 5).

Kamu diplomasisi çeşitli uygulama alanlarına sahiptir. Bunlar arasından medya, sahip olduğu geniş kitlelere erişebilme kabiliyeti sayesinde devletlerin kamu diplomasisi stratejileri ve bu yöndeki faaliyetleri açısından önemli işlevler görebilmektedir. Devletler sahip oldukları uluslararası medya kuruluşları aracılığıyla kendi bakış açılarını dünya kamuoyuna aktarmaktadırlar. Dolayısıyla küresel yayıncılık yapan medya kuruluşları kamu diplomasisi açısından oldukça önemlidir. Bu bağlamda 2015 yılında TRT bünyesinde kurulan TRT World kanalı Türkiye'nin kamu diplomasisi aracı olarak değerlendirilmiştir.

Türkiye'nin kamu diplomasisi stratejisinin bir parçası olarak değerlendirilen TRT World, tarihsel sosyolojik yaklaşımdan da yararlanılarak nitel yöntemlerden birisi olan vaka incelemesi/durum çalışması (case study) çerçevesinde ele alınmıştır. Bu çerçevede çoklu veri kaynaklarından ve veri toplama tekniklerinden yararlanılarak (istatistikler, yarı yapılandırılmış görüşme, dökümün incelemesi, röportajlar, vb.) "kuruluş süreci, amaç ve hedefleri, bütçesi, organizasyonel yapısı, personel politikası, hedef kitlesi, konumlandırılması, haber stratejisi, TV programları, resmi web sayfası ve sosyal medya hesapları" incelenerek TRT World'un kurumsal monografisi ortaya konulmuştur. Bu amaçla TRT World Haber Direktörü Fatih Er ve TRT World Şef Editörü (Managing Editor) ve Program Direktörü 
Resul Serdar Ataş ile 18 Temmuz 2017 tarihinde yarı yapılandırılmış görüşmeler yapılmıștır. Durum çalışması veya vaka incelemesi (case study) çalışmalarında genellikle bir toplumun, kurumun ya da küçük bir grup içindeki etkileşim ağı gibi konular ele alınmaktadır. Bir konunun derinlemesine ele alınıp incelenmesinde ilk kez Le Play (1806-1882) tarafından kullanılan monografi tekniğinden (Gökçe, 1999, 75, Akt: Zabun, 2007, 7) yola çlkarak monografi türleri arasında olan kuruluş monografilerinin ortaya konulması birikiminden de yararlanılmıștır

Bu makalede kamu diplomasisi aracı olarak medyanın kullanımı kapsamında örnek olay incelemesi (vaka-case) yöntemiyle TRT World incelenmiştir. Vaka incelemeleri genellikle betimleme yöntemleri arasında bağımsız bir yöntem olarak sayılmakta ve tek bir vaka ya da belirli sayıda tipik veya orijinal vakalar üzerinde yapılan çalışmalardır. $\mathrm{Bu}$ incelemelere temel oluşturacak veriler ise her türlü kaynaktan gelebilir (Kaptan, 1998, 66-67). TRT World'un incelenmesi sürecinde de vaka analizlerinde olduğu gibi çoklu veri kaynaklarından (istatistikler, yarı yapılandırılmış görüşme, dökümün incelemeleri, röportajlar, vb.) yararlanılmıștır. Çalışmada başvurulan veri toplama tekniklerinden birisi olan yarı yapılandırılmış görüşmeler ise bir dizi önceden belirlenmiş açık uçlu sorular etrafında organize edilmektedir, fakat görüşme esnasında görüşmeyi yapan kişi ile görüşülen kişi arasındaki diyalogdan doğan sorular da kullanılmaktadır (DiCicco-Bloom ve Crabtree, 2006, 315; Güler, Halıcıoğlu ve Taşğın, 2015, 115).

Bu çalışmada ilk olarak Türkiye'nin bir kamu diplomasisi stratejisine sahip olup olmadığı yayınlanan metinler üzerinden (doküman incelemesiyle) anlaşılmaya çalışılmış ve buradan hareketle kamu diplomasisi çalışmalarının ortaya koyduğu kavramsal çerçeve bağlamında Türkiye'nin kamu diplomasisi stratejisi içinde TRT World'e biçilen rolün tespit edilmesi amaçlanmıştır. Böylece TRT World'un Türkiye'nin kamu diplomasisi faaliyetlerindeki konumu ortaya çıkarılarak, Türk kamu diplomasisi için önemi belirlenmeye çalışılmıştır.

Türkiye'nin uluslararası TV yayıncılığındaki yeni arayışı olan TRT World'un kuruluş süreci, amaç ve hedefleri, bütçesi, organizasyonel yapısı, personel politikası, hedef kitlesi, konumlandırılması, haber stratejisi, TV programları, resmi web sayfası ve sosyal medya hesapları incelenmiştir. Çoklu veri toplama tekniklerinden yararlanılarak elde edilen bulgularla TRT World'un kurumsal yapısını ve kapasitesini tespit etmeye yönelik monografik bir çalışma yapılmıştır. Bu çalışma TRT World'u ele alan ilk araştırmalardan birisi olması ve Türkiye'nin kamu diplomasisi stratejisi ortaya koymaya çalışarak bu bağlamda uluslararası yayıncılığın konumunu irdelemesi bakımından önemlidir.

\section{Kavramsal Dönüşüm: Diplomasi, Kamu Diplomasisi ve Medya}

Diplomasi kavramı literatürde farklı şekillerde tanımlanmıştır. Britanyalı eski bir diplomat olan Ernest Satow $(1966,1)$ diplomasiyi bazen bağımsız devletlerin hükümetleri arasındaki resmi ilișkilerine odaklanan, bazen de bu devletlerin tâbi devletlerle olan ilişkilerine ya da barışçıl araçlarla ülkeler arasındaki işlerin yürütülmesi adına yapılan zeka ve taktik uygulamaları olarak tanımlamaktadır. Versan $(1995,89)$ diplomasiyi șiddete başvurmadan bir devletin diğer devletler üzerindeki çıkarlarını koruyabilmesi için gerekli olan bir vasıta olarak kabul etmektedir. Yapılan tanımlamalardan yola çıkarak diplomasi kavramı eski çağlardan beri yabancı gruplar arasındaki ilişkilerin belirli temsilciler aracılığıyla 
ve müzakere teknikleri kullanılarak yönetilmesi olarak tanımlanabilir. Diplomasi ayrıca dış politikanın şekillendirilmesi sürecinde belirleyicidir.

Kamu diplomasisinin kavramsallaştırılması İkinci Dünya Savaşı sonrası döneme gelmesi, içinde bulunulan konjonktürün bir neticesi olarak değerlendirilebilir. Soğuk Savaş'ın yaşandığı yıllarda Sovyetler Birliği'nin uyguladığı komünizm, insanları baskı altında tutmakta ve bireylerin fikirlerinde farklılaşmanın ortaya çıkmasına izin vermemekteydi. Bu durumu firsata çevirmek isteyen ABD ve diğer Batı Bloku devletleri Sovyetleri hedef alan, temelinde insan hakları ve özgürlükler olan propaganda faaliyetlerine girișmiștir. Kamu diplomasi böyle bir konjonktürde ortaya çıkmıştır (Karadağ, 2016, 10-11). Özellikle uydu teknolojisinde yaşanan gelişmelerin küresel politikaların şekillenmesindeki etkisinin artması (Seib, 2008, ix), kamu diplomasisinin ortaya çıkmasındaki en başat etkenlerden biri olarak kabul edilebilir. ABD'de 1960'lı yıllarda ortaya çıkan kamu diplomasisi kavramı, özellikle 11 Eylül 2001 itibariyle dünya kamuoyunda kalpleri kazanma ve zihinlerde yer etme sanatı olarak ön plana çıkmıştır (Sancar, 2015, 441). Devletlerin uluslararası ilişkiler politikalarına dünya kamuoyunda meşruiyet kazandırması için sadece diplomasinin yeterli olmaması; başta sivil toplum kuruluşları olmak üzere farklı organizasyonların da desteğine ihtiyaç duyması kamu diplomasisinin önemini artıran bir başka etken olarak öne sürülebilir.

Geleneksel diplomasi ile kamu diplomasisi arasındaki farklılığı anlamak için Snow'un $(2009,6)$ çizdiği çerçeve önemlidir. Ona göre geleneksel diplomasi, hükümetten hükümete ilişkilerdir ve bu duruma eski ABD Dışişleri Bakanı Condoleeza Rice'ın başka bir ulus devletin dışişleri bakanının masasında oturmasını örnek göstermektedir. Geleneksel diplomasiden farklı olarak kamu diplomasisinde etkileșimin stratejik bir rol oynadığını belirten Özkan $(2014,2)$, kamuoyunun belirleyici rolünün arttığı yeni uluslararası sistemde kamu diplomasisinin ön plana çıktığını vurgulamaktadır.

Joseph S. Nye’e $(2008,95)$ göre kamu diplomasisi, hükümetlerin diğer ülkelerin kamularıyla iletişime geçmek ve onları kendine yakınlaştırmak için kullandığı, yumuşak gücü ortaya çıkaran kaynaklardan oluşan bir araçtır. Kamu diplomasisi, yayın yapma, kültürel ihracatı finansal olarak destekleme, karşılıklı değiş tokuş aracılığıyla bu potansiyel kaynaklara dikkat çekmeyi amaçlamaktadır. Nye’ın kamu diplomasisi tanımından bahsederken yumuşak güç kavramının üzerinde de durmak gerekmektedir. Dünyada yaygın olarak bilinen "güç" anlayışındaki değişim de kamu diplomasisinin üzerinde daha fazla durulmasının temel sebeplerindendir. Nye (2004, 7-11), yumuşak gücü "baskı ya da para ile satın almadan ziyade cazibe sayesinde istenilen şeyi elde edebilme yeteneği" ş̧eklinde tanımlamaktadır. Yumuşak gücün dayanakları bir devletin kültürü, politik idealleri ve politikalarının çekiciliğindedir. Bir devletin uyguladığı politikalar, diğer devletlerin gözünde meşru kabul edildiği vakit yumuşak güç pekişecektir.

Kalın'a göre $(2011,8)$ ise yumuşak güç için inandırıcılık ile ikna kabiliyeti önemlidir. Kalın, bir devletin yaptıklarının diğer devletlerin gözünde meşru olabilmesinin "karşı tarafı inandırıcı argümanlar ve rasyonel politikalarla ikna ederek mümkün" olacağını ifade etmektedir. Devletlerin safi askeri ve ekonomik gücüne dayalı olarak dış politika amaçlarını gerçekleştirmeye çalışmaları, özellikle iletişim teknolojilerinin son derece geliştiği bir dönemde oldukça sakıncalıdır. Çünkü insanların giderek daha 
kolay bir şekilde bilgiye erişebiliyor olmaları, onların her an olup biten durumlardan haberdar olmalarını sağlamakta ve reaksiyon gösterebilmelerine aracılık etmektedir. $\mathrm{Bu}$ sebeple bir devlet dış politikada elde etmek istediği menfaatlere ulaşırken, diğer devletlerin kamuoylarında kendilerini meşru kılmaları bir gereklilik halini almaktadır. Bu nedenle yumuşak güç kavramı giderek daha da ön plana çıkmaktadır.

Kamu diplomasisi uygulamalarının farklılaşmasında ve gelişmesinde iletişim teknolojilerinde yaşanılan ilerlemelerin rolü oldukça büyüktür. Medya, bir ülkenin sahip olduğu hikâyeyi diğer ülkelerin kamuoylarına aktarabilmesinde en önemli araçlardan biri konumundadır. Bu sebeple iletişim teknolojilerindeki gelişmeler, kamu diplomasisi uygulayıcılarının elini kuvvetlendirmektedir. Uluslararası iletişim çabalarının tarihin her döneminde başvurulan bir yöntem olduğunu belirten Güngör'e $(2013,51)$ göre, iletişim teknolojilerinde yaşanan gelişmeler sayesinde uluslararası kamuoyuna daha hızlı erişme kapasitesine sahip olan medyanın etki alanı artmaktadır.

Kamu diplomasisi açısından uluslararası kamuoyu oluşturma noktasında medyanın çok önemli olduğu bir gerçektir. Küreselleşen dünyada lider konumda olan bütün ülkeler uluslararası arenada medyanın gücünden faydalanmaktadırlar (Ertekin, 2012, 334-335). Medya devletlerin ya da kurumların faaliyetlerini aktarmada en büyük güç konumundadır. Küreselleşme ve teknoloji alanında yaşanan gelişmeler hem medyanın hem de iletişimin gücünü artırmış, etki alanını genişletmiştir. Kamu diplomasisinin sahip olduğu uygulama alanları arasında medya, dünyanın dört bir yanındaki insanlara erişebilme ve onlar üzerinde belirli bir etki yaratabilme gücü sayesinde öne çıkmaktadır (Yıldırım, 2015, 173).

Özellikle haber kuşaklarının televizyon ekranlarında yer almaya başlaması ve bu haber kuşaklarının farklı bakış açılarıyla düzenlenmesiyle kitle iletişim araçları önemli bir güce sahip olmaya başlamıștır. Bu gücün kaynağı ise medyanın "kamuoyunu oluşturma kabiliyetine" sahip olmasıdır. Böylece kitle iletişim araçları yani medya 20. yüzyılın en etkili siyasal güçlerinden biri olarak karşımıza çıkmaktadır (Bektaş, 2013, 120-121). Bu ifadelerden yola çıkarak medyanın sahip olduğu gündem belirleme kabiliyetinin kamu diplomasisi için vazgeçilmez bir öneme sahip olduğu anlaşılmaktadır.

Uluslararası medya kuruluşlarının ülkeleri nasıl anlattığı önemlidir. Çünkü uluslararası toplumun zihninde ülkeler hakkında oluşacak algıyı etkileyebilmektedirler. Bir ülke yabancı basında ne kadar olumlu anılırsa o denli yatırım ve turist çekebilmekte; yumuşak gücünü artırabilmektedir (Ekşi, 2014, 114-115). Kamu diplomasisi aracı olarak medyanın kullanılması sürecinde dikkat edilmesi gereken en önemli nokta medyanın ürettiği yayın içerikleridir. Toplumların birbirlerini anlayıp yakınlaşmalarını sağlayacak olan yegâne şey bu yayın içerikleridir. Yayın içeriklerinin konunun profesyonelleri tarafından, özellikle ortak paydalara odaklanıp farklılıkları vurgulamaktan kaçınarak hazırlanması gerekmektedir. Bu doğrultuda stratejik vizyonu olan bir yayın politikasına ihtiyaç duyulmaktadır (Özkan, 2017).

Devletler dünya kamuoyunda olumlu anılmak için sadece yabancı medya kuruluşlarının haberlerinde yer almakla yetinmezler, aynı zamanda sahip oldukları uluslararası medya kuruluşlarını da bu amaçla kullanırlar. Ancak ülkelerin sahip oldukları uluslararası medya kuruluşlarının tek misyonu ülkeleri hakkında dünya 
kamuoyuna bilgi vermek değildir. Bu medya kuruluşları aynı zamanda dünyanın farklı bölgeleri hakkında haberler sunarken, tarafsızlığını tamamen koruyamayarak kendi ülkelerinin bakış açılarıyla olayları yorumlamaktadırlar (İnceoğlu, 2015). Batı merkezli bazı uluslarlarası medya kuruluşları Orta Doğu'ya yönelik içeriklerinde terör, kaos, açlık gibi zihinlerde olumsuz çağrışımlar yapan kavramalara ağırlık verirken; $A B D$ ve diğer güçlü Avrupa devletlerini demokrasi, gelişmişlik ve insan hakları gibi olumlu çağrışım yapan kavramlarla sunmaktadırlar (Erzen, 2014, 148). Bu bağlamda uluslararası alanda gücü elinde bulunduran medya kuruluşlarına sahip olan devletler, kamuoylarını yönlendirme ve şekillendirmede oldukça etkilidirler. $\mathrm{Bu}$ gücü verimli bir şekilde kullanan devletler ise dış politika uygulamalarının meşruiyetini sağlamada önemli firsatlar elde etmektedirler.

Kamu diplomasi açısından bakıldığında bazı televizyon kanalları ön plana çıkmaktadır. Zamanla dünyanın her köşesine yayılan, her eve giren televizyonun hem görsel hem de işitsel olarak sunduğu içeriklerin tüketilmesi son derece kolaydır. Bu sebeple uluslararası yayın yapan televizyon kanalları, kamu diplomasisi uygulayıcıları için vazgeçilmez birer araç konumundadırlar. Geniş ağları sayesinde dünyada olup biten her olay hakkında gündem olușturabilme kabiliyetine sahip olan uluslararası yayın kuruluşları, kamu diplomasisi uygulayıcılarına önemli avantajlar sağlamaktadır. Bu bağlamda televizyon aracılığıyla kamu diplomasisi uygulayıcıları geniş kitlelere ulaşarak kendi ülkeleri hakkında bilgi verebilmekte ya da ülkelerinin bakış açılarıyla olayları yorumlayarak hedef kitlelerine aktarmaktadırlar. $\mathrm{Bu}$ tür uluslararası yayın yapan kuruluşlara CNN (Cable News Network) ve El Cezire gibi televizyon kanalları örnek gösterilebilir. Bu noktada CNN'in ön plana çıkması Körfez Savaşı'nın yaşandığı döneme rastlamaktadır. 1990-1991 Körfez Savaşı yıllarında uluslararası ilişkilerde küresel bir aktör haline gelen CNN, gerek elde ettiği başarılar gerekse de yayınlarıyla uzun zamandır dünya çapında radyo yayıncılığı yapan BBC, NBC, Star gibi yayın kuruluşlarına küresel televizyon ağları kurmaları konusunda ilham kaynağı olmuştur (Gilboa, 2005, 27). CNN'in bu denli ön plana çıkmasıyla birlikte literatürde CNN etkisi (CNN effect) üzerinde durulmaya başlanmıştır (Robinson, 2002, 8).

CNN'in dışında özellikle BBC, DW, El Cezire ve CGTN televizyon kanalları da kamu diplomasisi faaliyetleri yürüten kanallar olarak değerlendirilebilir. BBC Dünya Servisi'nin gündüz döngüsünü yöneten bir editör, kanalın İngiltere'nin yumuşak gücünü yansıtan bir politikaya sahip olduğunu ve Britanya'nın çeşitli sorunlar yaşayan bir ülke olmasına rağmen kanalın yayın politikaları sayesinde ülkenin dünya kamuoyunda güvenilir ve ifade özgürlüğüne değer veren bir imaj oluşturmasına katkı sağladığını belirtmektedir (Yanardağoğlu, 2014, 124). DW, dünyadaki güncel gelişmeleri Alman bakış açısıyla gösteren küresel bir ses olarak tanımlanmaktadır (Silcock, 2002, 342). El Cezire'nin dünyanın önde gelen kanalları arasında yer alması ise Katar'ın dünya gündemine oturması ve Katar'a yönelik yürütülecek yanlış politikaların dünyanın gündemine gelebileceği gibi durumlar ülke açısından önemli bir caydırıcı unsurdur (Devran, 2015, 284-285).

\section{Türkiye'nin Kamu Diplomasisi Stratejisi}

Türkiye'nin kamu diplomasisi stratejisi, Kamu Diplomasisi Koordinatörlüğü'nün (KDK) ortaya koyduğu metinlerden hareketle belirlenmeye çalışılmıştır. KDK'nin temel amacı “Türkiye'nin uluslararası toplumda tanıtımını yapmak ve saygınlığını artırmak hedefi doğrultusunda kamu kurum ve kuruluşları ile bütün zenginlikleri 
ve tecrübeleriyle sivil toplum kuruluşları arasında koordinasyon ve işbirliğini sağlamak" ve "hikâyenizi karşı tarafa doğru bir şekilde anlatabilmek" şeklinde ifade edilmiştir (KDK, 2017).

KDK'nin ortaya koyduğu bu çerçevede Türkiye'nin sahip olduğu yumuşak gücün kaynakları şu şekilde belirlenmiştir (KDK, 2017):

- Türkiye'nin yumuşak gücünün temel kaynaklarından biri sahip olduğu demokrasi tecrübesidir. Türkiye'de demokrasinin giderek daha da kurumsallaşması ve halk tarafından benimsenmesi, Türkiye'nin bölgesel ve küresel anlamda önemli bir aktör olmasına katkı sağlamaktadır.

- Türkiye'nin sahip olduğu en önemli yumuşak güç kaynaklarından birisi de Balkanlardan Orta Asya'nın içlerine kadar uzanan tarih ve kültür derinliğidir. Türkiye'nin bu coğrafyalarda sahip olduğu tarihi birikimi ve kültürel derinliği hem bölge dinamiklerini harekete geçirmekte hem de yeni etkileşim alanlarının oluşmasına neden olmaktadır.

Türkiye'nin kamu diplomasisi stratejisi şu şekilde ifade edilebilir (KDK, 2017)::

- Türkiye'nin tarihi ve kültürel bağlarının olduğu Balkanlar'da ve Orta Doğu'da bir cazibe merkezi haline gelmesi için özgürlük-güvenlik dengesini tutarlı bir şekilde kurması ve demokratik fırsat alanlarını genişletmesi gerekmektedir.

- Kamu diplomasisi açısından en önemli unsurlardan birisi ulusal ve küresel boyuttaki politikaların belirlenmesindeki etkisi giderek artan kamuoyudur. KDK hem ulusal hem de uluslararası politika süreçlerini yakından izlemekte ve ayrıca basın aracılığıyla dünya kamuoyuna aktarmaktadır. Günümüzde artık kamuoyunun desteğini almadan ekonomiden dış politikaya, enerjiden çevreye kadar birçok konuda politika belirlemek ve uygulamak mümkün değildir. $\mathrm{Bu}$ bağlamda başarılı bir kamu diplomasisi için izlenen politikaların kamuoyuna rasyonel, ikna edici ve savunulabilir bir şekilde anlatılması gerekmektedir.

Bu stratejinin yanı sıra İbrahim Kalın'ın KDK'nin resmi web sayfasında yer alan "Türk Dış Politikası ve Kamu Diplomasisi” başlıklı yazısında yaptığı Türk kamu diplomasisi tanımı da strateji noktasında önemli bilgiler içermektedir. Kalın’a göre Türk kamu diplomasisi “Türkiye'nin yeni 'hikâyesi'nin etkin ve kapsamlı bir şekilde dünya kamuoyuna anlatılması faaliyetidir. Bu faaliyetlerin muhtevasını belirleyen, Türkiye'nin tarihinden ve coğrafyasından tevarüs ettiği birikimidir. Türk dış politikasının derinlik kazanması, bu birikimi stratejik bir değer haline getirmesiyle doğrudan orantılıdır" şeklinde tanımlamaktadır ve bu doğrultuda stratejiler belirlemektedir (Kalın, 2017). KDK'nin metinlerinde ve ilk koordinatörü İbrahim Kalın'ın kaleme aldığı metinlerde vurgulanan “Türkiye'nin yeni hikâyesi” ya da "Yeni Türkiye" kavramsallaştırması, Türkiye'nin kamu diplomasisinin hedeflerini ortaya koyan bir politikanın ve bu politakaya dayalı olarak üretilecek ve geliştirilecek söylemlerin dayandırılacağı bir zemin olarak nitelendirilebilir.

Ülkelerin yürüttükleri kamu diplomasisi faaliyetlerinde, ilgili her kurum ve kuruluşa farklı görevler düşmektedir. Türkiye'nin kamu diplomasisi faaliyetleri bir bütün olarak düşünüldüğünde, KDK'nin işbirliği içinde olduğu kurum ve kuruluşların görevleri şu şekilde gösterilebilir: Devlet ayağındaki karar verme ve uygulamaya geçirme aşamasını Cumhurbaşkanlığı, Başbakanlık, Dışişleri Bakanlığı ve Kültür ve Turizm Bakanlığı; uluslararası yayıncılık aşamasını TRT, AA ve BYEGM; kültürel 
ve sosyal altyapı oluşturma aşamasını Yunus Emre Enstitüsü ve TÜRKSOY; yardım ve kalkınma faaliyetleri aşamasını TİKA sağlamaktadır (Yıldırım, 2015, 287). Ayrıca SETA ve TASAM gibi düşünce kuruluşları da Türkiye'nin kamu diplomasisi faaliyetlerine yaptıkları bilimsel araştırmalar ve projeler ile katkı sağlamaktadırlar.

\section{Türkiye'nin Uluslararası TV Yayıncılığında Yeni Bir Arayış: TRT World}

Türkiye'nin uluslararası televizyon yayıncılığı -kamu yayıncılı̆̆ı özelinde- TRT bünyesinde gerçekleştirilmektedir. TRT bünyesinde daha önce farklı dillerde kanallar kurularak (TRT Int, TRT Kürdi, TRT Avaz, TRT Belgesel, TRT-El Arabia) uluslararası yayıncılık anlamında girişimlerde bulunulmuştur. Son olarak ise 2015 yılında Türkiye'nin dünyaya açılan penceresi olarak ifade edilen ve İngilizce yayın yapan TRT World kanalı kurulmuştur. Türkiye'nin sahip olduğu yaklaşık iki yüz yıllık medya deneyimi ve devamında yapılmaya çalışılan uluslararası yayıncılık arayışları çerçevesinde TRT World'un değerlendirilebilir olduğu düşünülmektedir. Buna TRT'nin 50 yıllık yayın tecrübesi eklendiğinde TRT World'un, Türkiye'nin daha önce tecrübe ettiği uluslararası yayıncılık girișimlerinde olduğu gibi ülkenin, dünyada olup biten olaylara yönelik bakış açısını dünya kamuoyuna aktarma amacını taşıdığı görülmektedir. TRT çatısı altında tüm dünyaya Türkçe yayınlar yapılmaktadır. Ancak bu kanallardan farklı olarak TRT World'un TRT'nin dünyaya açllan bir penceresi olma amacına sahip olduğu özellikle vurgulanmaktadır (Pala, 2015). TRT World'u ortaya çıkaran tarihsel-toplumsal bağlam açısından önemli bir süreç olan 2000'li yıllardaki metinlerde bunu görmek mümkündür. Ayrıca 2000 yılında yayınlanan Sekizinci Beş Yıllık Kalkınma Planı kapsamında hedeflenen uzun vadeli gelişmenin -2001 ile 2023 yıllarını yani cumhuriyetin 100. yılını kapsayan- temel amaç ve stratejisinde belirtilen etkili düzeyde bir dünya devleti olma, bölgesel ve küresel düzeylerdeki kararlarda etkin söz sahibi olma gibi nesnel amaçlar TRT World'un kuruluşunu hazırlayan bir bașka etken olarak değerlendirilebilir (Devlet Planlama Teşkilatı, 2000).

Tüm bu tespitler göz önünde bulundurulduğunda, TRT World'un, Türkiye'nin kamu diplomasi stratejisi açısından yüklendiği misyonu görmek amacıyla kanalın yapısını incelemenin oldukça önemli olduğu gerçeği gün yüzüne çıkmaktadır. Vaka incelemesinin yapılmasına imkân verecek şekilde TRT World'un yapısını ortaya çlkaracak bir çaba çerçevesinde belirlenen on iki (12) unsur ve madde ile monografik bir çalışma yürütülmüştür. Bu amaçla "Kuruluş Süreci, Amaç ve Hedefler, Bütçe, Organizasyonel Yapı, Personel Politikası, Hedef Kitlesi, Konumlandırılması, Haber Stratejisi, TV Programları, Dağıtım Ağı, Resmi Web Sayfası, Sosyal Medya Hesapları" çoklu veri kaynaklarından yararlanılarak ayrı ayrı incelenmiştir.

\section{Kuruluş Süreci}

Türkiye'nin 2002 yılından itibaren bölgesel ve küresel bir aktör olarak önemli bir ülke olduğuyla ilgili başta uluslararası ilişkiler disiplininde olmak üzere birçok çalışma ve tartışma yapılmaktadır (Bkz. Aydınlı, Kurubaş ve Özdemir, 2015). Siyasi, ekonomik ve dış politika başta olmak üzere 2000'li yıllar Türkiye'sinin tarihsel koşulları TRT World'un ortaya çıkmasına yol açtığı açıktır. Bunu söylemeye imkân veren kaynaklar hem kalkınma planları ve strateji metinlerinde hem kanalın söylemlerinde hem de bu alanda yapılan akademik çalışmalarda karşımıza çıkmaktadır (Bkz. Devran, 2015; Canbey, 2017). Türkiye'nin tecrübe ettiği Gezi Parkı eylemlerinin uluslararası medyadaki yansımaları, TRT World projesinin gerçekleștirilmesini hızlandırdığı da söylenebilir (Devran, 2015, 290). 
TRT World'un açılış programında konuşan Cumhurbaşkanı Recep Tayyip Erdoğan, TRT World'den beklentisini "milletimizin gerçeklerini, en iyi televizyonculuğu yaparak dünyaya anlatmasını bekliyoruz" şeklinde ifade etmiştir. Aynı programda TRT World'un tanıtımını yapan TRT Genel Müdürü ${ }^{1}$ İbrahim Eren ise Türkiye'nin 2002 yılı sonrası her alanda ilerleme sağladığını ve önemli bir yükselişe geçtiğini; TRT World'un de bu yükselişe paralel bir şekilde ortaya çıktığını dile getirmiştir (TRT Haber, 2016). TRT World'un 18-19 Ekim 2017 tarihlerinde düzenlemiş olduğu TRT World Forum'da konuşan Başbakan Binali Yıldırım ise dünya medyasının Orta Doğu'ya karşı kayıtsız kalması, bölgeye dair haberleri hassasiyet göstermeden yapıyor olmasının karşısında TRT World'un duracağını belirtmiştir. TRT World'un kuruluşu tetikleyen gelişmelerin ise sesini duyuramayan insanların sesini duyurma ve bölgeyi dünyaya doğru anlatma ihtiyacı olduğunu ifade etmiştir (TRT Haber, 2017a).

\section{Amaç ve Hedefler}

Amaç ve hedeflerinin tespiti, kamu diplomasisi kavramının anlam çerçevesi ve uygulama alanları açısından TRT World'u analiz etmeyi ve değerlendirmeyi kolaylaştıracaktır. Bu açıdan çeşitli kaynaklardan yararlanarak kanalın amaç ve hedefleri tespit edilmeye çalışılmıştır. TRT World'un resmi web sayfasında kanalın amacına ve hedefine yönelik bazı açıklamalar söz konusudur. Buna göre haberleri okumak, dinlemek ve izlemek TRT World'un izleyicisi için bir son olmamaktadır. TRT World izleyicilerinden bir reaksiyon, düşünce kalıplarında bir değişim, sosyal meselelerin farklı bir şekilde algılanması ve çeşitli kültürler ile etnisitelerin daha açık, derinlemesine anlaşılması gibi cevaplar almayı amaçlamaktadır. TRT World izleyicilerini kanalın arzularının ve izleyicilerin ilhamının bir parçası olmaya davet etmektedir. Kanal izleyicilerini küresel bir bilince sahip küresel vatandaşlar olarak tanımlamakta, onların hikâyelerin merkezinde olmayı hak ettiklerine inanmaktadır (TRT World, 2017a). Eren'in ifadelerinden hareketle kanalın İngilizce yayın yapması nedeniyle geniş kitlelere ulaşması ve dünyada gerçekleşen olayları hem Türkiye'nin hem de bu coğrafyanın nasıl değerlendireceğini anlamak için en önemli başvuru kaynağı olması beklenmektedir. Ayrıca TRT World'un Türkiye'nin kendi argümanlarını dünyaya anlatabileceği bir televizyon kanalına olan ihtiyacını karşılamak için kurulduğu belirtilmektedir (Pala, 2015). TRT World'un resmi web sayfasında ise kanalın misyonu "anlayışı arttırmak, varsayımlara meydan okumak, tartışmaları cesaretlendirmek, pozitif davranışları etkilemek" şeklinde ifade edilirken; kanalın vizyonu ise "pozitif değişim için katalizör olmak" şeklinde belirtilmektedir (TRT World, 2017a).

$\mathrm{Bu}$ çalışma için kendisiyle görüşülen TRT World Haber Direktörü Fatih Er'in ifadelerinden TRT World'un kuruluşundaki en büyük amacın Türkiye'ye dair merak edilen konularda ulaşılacak ilk kaynak olmak olduğu anlaşılmaktadır. Türkiye hakkında herhangi bir durumla ilgili insanlar Google gibi arama motorlarında arama yaptıklarında karşılarına ilk olarak TRT World'un çıkması istenmektedir (F. Er ile kişisel iletişim, 18 Temmuz 2017). Çalışma kapsamında görüşülen kanalın diğer bir yöneticisi olan TRT World Program Direktörü Resul Serdar Ataş ise "şu veya bu şekilde bir kamu yayıncılığı yapan bir kanal olarak TRT World'un kaderiyle Türkiye'nin kaderini birbirinden ayrıștırmamak gerekiyor" ifadelerini kullanarak 
TRT World'un Türkiye açısından önemine vurgu yapmaktadır (R. S. Ataş ile kişisel iletişim, 18 Temmuz 2017).

Ataş da “TRT World'un Türkiye'nin dünyaya açılan penceresi olma” iddiasını destekler nitelikte cevaplar vermenin yanı sıra kanalın -TRT World ile ilgili yayımlanan bir çalışmada da belirtilen- kendi tezlerini uygun bir dille dünyaya anlatabilmek için global bir dil oluşturma amacına sahip olduğunu vurgulamıștır (Bkz. Devran, 2015). Ataş'ın ifadeleri şu şekildedir:

TRT World'un temelde burada misyonu şu, bir tarafta kamu yayıncılığının gerektirmiş olduğu ahlaki ilkelere uymak bir taraftan da global bir dil oluşturmak, öte taraftan da aynı zamanda Türkiye'nin pozisyonunu makul bir dille dünyaya anlatabilmektir. Aynı zamanda global izleyicinin, global kamuoyunun da doğru, ispatlanmış, doğrulanmış, "verify" edilmiş bilgilerini sağlamak. Bu anlamda TRT World evet Türkiye'nin dünyaya açılan kapisı olmuş oluyor.

Türkiye'nin uluslararası arenada yeteri kadar etkili olamamasının nedenlerinden biri de kendi sesini dünyaya tam anlamıyla duyuramaması olarak ifade edilebilir. $\mathrm{Bu}$ bağlamda TRT World'un kurulması ve konumlandırılması, küresel TV kanallarıyla rekabet edebilmesi ve Türkiye'nin yayıncılık anlayıșının değiștiğini kanıtlayan bir adım olarak değerlendirilebilir (Devran, 2015, 289). TRT World Haber Direktörü Fatih Er kanalın uluslararası kamuoyunu bilgilendirmeyi amaçladığını, bu yönüyle de Türkiye için önemli bir kamu diplomasisi aracı olduğunu ifade etmektedir (F. Er ile kişisel iletişim, 18 Temmuz 2017). TRT World Program Direktörü Resul Serdar Ataş kanalın Türkiye'nin jeopolitik pozisyonun dünyaya makul bir dille anlatmayı amaçlaması nedeniyle bir kamu diplomasisi aracı olduğunu ifade etmektedir (R. S. Ataş kişisel iletişim, 18 Temmuz 2017).

TRT World'un dünya üzerindeki büro sayılarını arttırmak ve küresel yayıncılık yapan kurumlar içerisinde ilk sıralarda olmak gibi hedefleri olduğunu belirten Resul Serdar Ataş'ın ifadeleri şu şekildedir (R. S. Ataş ile kişisel iletişim, 18 Temmuz 2017):

Şöyle söyleyebilirim, bizim doğrudan şu anda kısa vadedeki hedeflerimizden bir tanesi örneğin Singapur'daki yayın merkezimizin aktifleştirilmesi. Biz henüz hâla 24 saatlik yayında değiliz. Birkaç ay içerisinde Londra'daki haber saatimizi arttırmak, Washington'daki haber saatimizi artırmak, Singapur'da yayın merkezimizi kurup orda da aynı zamanda günlük yayına başlamak ve 24 saati geçmek.

TRT World'un yöneticilerinin ifade ettikleri hedefler ile kanalın çeşitli metinlerde belirtilen "Türkiye'nin küresel bir sesi olma” amaçları arasında bir uyum olduğu anlaşılmaktadır. Bu hedefler göz önünde bulundurulduğunda kanalın küresel çapta gündem oluşturma kabiliyetini arttırma amacına sahip olduğu anlaşılmaktadır. Bu sayede TRT World Türkiye'nin argümanlarını dünyaya aktarma açısından çok daha etkili bir kamu diplomasisi aracı olarak Türkiye'nin kamu diplomasisi stratejisi çerçevesinde faaliyetlerini yürüttüğü sonucuna varılabilir.

Uluslararası yayıncılık bağlamında küresel bir güç olmayı hedefleyen TRT World'un amaçları arasında küresel yayıncılık yapan BBC, Deutsche Welle gibi habercilik amaçlarının yanı sıra internet siteleri üzerinden yabancı dil öğrenme imkânı da sunmak yer almaktadır. TRT World'un da benzer bir uygulamayı kısa vadede değil ama daha sonra planladığı, Resul Serdar Ataş’ın “şu anda önceliğimiz birincil derecede operasyonel boyutu, haberin güvenilirliği, derinliği ve çeşitliliği öncelikle sağlamak 
zorundayız. Çünkü biz öncelikle bir haber kanalıyız" şeklindeki ifadelerinden anlaşılmaktadır (R. S. Ataş ile kişisel iletişim, 18 Temmuz 2017).

TRT World'un yöneticileri kanalın kuruluşundan itibaren geçen 2 yıllık süreçte belirlenen hedefler doğrultusunda başarılı bir şekilde ilerlediğini ifade etmektedirler. Gerek personel konusunda gerekse de dağıtım konusunda istenilen noktalara gelinmesi ya da yaklaşılması önemli bir gelişmedir. Fatih Er'in konuyla ilgili ifadeleri şu şekildedir (F. Er ile kişisel iletişim, 18 Temmuz 2017):

\begin{abstract}
Bizim kendimize koymuş olduğumuz bazı "peak" noktalar var. Biz bunları adım adım ilerliyoruz. Özellikle hedeflerimizden bir tanesi -başta da söylediğim gibi- gençleri yetiştirmekti. (...). Burada belli bir noktaya geldiğimizi düşünüyorum. Biraz daha gayret etmemiz gerektiğine inanıyorum. Ki hedefimizi tutturduk diyebilirim adam yetiştirme konusunda. "Distribution" yani dağıtım konusunda öndeyiz bile diyebilirim.
\end{abstract}

Resul Serdar Ataş ise uluslararası bir televizyon kuruluşunun inşa süresinin oldukça zor olduğunu, El Cezire'nin 5 yılda aldığı mesafeyi TRT World'un iki yılda aldığını ve bu anlamda TRT World'un önemli adımlar atarak amaç ve hedeflerine ulaşma yolunda olduğunu belirtmiştir (R. S. Ataş ile kişisel iletişim, 18 Temmuz 2017).

TRT World'un 18-19 Ekim 2017 tarihlerinde düzenlemiș olduğu TRT World Forum’a dünyanın birçok ülkesinde önemli devlet adamları, medya profesyonelleri ve akademisyenler katılmıștır. Bu Forum'un kendisi de bir kamu diplomasisi faaliyeti olarak ve TRT World açısından bir halkla ilişkiler faaliyeti olarak görülebilir. Forumda TRT Genel Müdürü İbrahim Eren, TRT’nin artık dünya ile rekabet edebilecek düzeyde olduğunu ve TRT World'un de TRT'nin tecrübelerinden faydalandığını ifade etmiştir. Aynı şekilde o dönemin başbakan yardımcısı olan Bekir Bozdağ ise TRT World'un Türkiye Cumhuriyeti'ni temsil ettiğini, dünyadaki tek sesliliği bozmak amacına sahip olduğunu ve algıların doğru bir şekilde oluşturulması noktasında kanalın önemli olacağını belirtmiştir (TRT World Research Center, 2017).

\title{
Bütçe
}

Kanalın yapısını, faaliyetlerini ve gelecek hedefleri dâhil bir medya organizasyonu olarak TRT World'un sahip olduğu mali güç ve kaynaklar çalışmamız açısından kanalı analiz ederken önemli bir unsur ve veri kaynağı olarak görülmektedir. Bu çerçevede mümkün olan tüm kanallar ve veri kaynakları kullanılarak kanalın bütçesi ve mali gücü tespit edilmeye çalışılmıştır. TRT World, TRT’nin çatısı altında kurulan bir kanal olarak bütçesini toplanan vergiler üzerinden elde etmektedir. Kanala vergiler üzerinden ayrılan bütçe net olarak bilinmemektedir. Çünkü TRT’nin altında onlarca TV kanalı, radyo istasyonu ve çeşitli basılı yayın organları bulunmaktadır. Bunların hepsine toplanan vergiler üzerinden ayrı ayrı bütçelendirmeler yapılmaktadır.

İbrahim Eren, TRT World'un aynı kulvarda olduğu BBC, CNN, El Cezire gibi kanallarla bütçe bakımından yarışmasının mümkün olmadığını, bu kanalların bütçelerinin TRT World'un bütçesinin neredeyse on katı olduğunu ve son olarak TRT bünyesindeki kanallar içinde bile en pahalı kanal olmadığını ifade etmiştir (Yıldızalp ve İleri, 2017). TRT World yöneticilerinden Resul Serdar Ataş da bu durumu destekler nitelikte ifadeler kullanmış ve kanalın sahip olduğu makul bütçeden maksimum fayda alınmaya çalıșıldığı üzerinde durmuştur (R. S. Ataş ile kişisel iletişim, 18 Temmuz 2017). 
Uluslararası yayıncılık yapan bir televizyon kuruluşunun işleyişi gereği maliyetinin oldukça yüksek olması beklenmektedir. Yabancı personellerin çalıştırılması, dünyanın farklı şehirlerinde büroların, temsilciliklerin açılması, oralarda çalışacak personelin istihdam edilmesi gibi yüksek maliyeti olan bir iş söz konusudur. TRT World kendisine rakip olarak gördügü BBC, CNN, El Cezire'nin onda biri oranında bir bütçeyle operasyonlarını sürdürmektedir. Bu durum ise TRT World'un adı geçen kanallarla rekabet düzeyinin azalmasının sebeplerinden biri olarak gösterilebilir.

\section{Organizasyonel Yapı}

TRT World'un monografik bir incelemeye tabi tutulabilmesi açısından kanalın organizasyonel yapısı ve dünya üzerindeki bürolarının tespiti çalışma açısından ihtiyaç duyulan bilgilerdendir. TRT World uluslararası yayıncılık yapan, büyük bir organizasyon olarak kurulmuştur. TRT World Haber Direktörü Fatih Er kanalın TRT'den farklı olarak ABD ve İngiltere'de 13-14 kişinin çalıştığı bürolarının olduğunu ve buralardan hali hazırda yayınların yapıldığını belirtmektedir. Yakın zamanda Singapur'da da bir büronun açılması planlanmakta ve TRT bünyesinde yer alan 14-15 temsilcilikte de TRT World'un personeli yer almaktadır. Kanalın organizasyonel yapısı ele alındığında ise televizyon merkezi içinde input (girdi) ve output (çıktı) olarak ikiye ayrılmaktadır. Input ekrana çıkacak her şeyin hazırlanmasıyla, output ise onların ekrana çıkmasını sağlamakla görevlidir (F. Er ile kişisel iletişim, 18 Temmuz 2017).

TRT World kendi içerisinde vizyon (vision), haber, program, dijital, pazarlama ve iletişim (marketing and communication), teknik, operasyon, yaratıcı (creative) olmak üzere sekiz farklı departmana ayrılmaktadır. Vizyon departmanı küresel etkinlikleri ve forumları düzenlerken, aynı zamanda hem araştırma hem de yayın işlerini yürütmektedir. Dijital departman ise TRT World'un bütün dijital platformlardaki görünürlügünü artırmak için çalışmaktadır. Bunların yanı sıra yaratıcı departman da kanalın ürettiği işlerin en etkileyici şekilde izleyicisiyle buluşmasını sağlamaya çalışmaktadır. Departmanlar arasında hiyerarşik bakımdan bir eşitlik söz konusudur. Bu departmanlar ise içeride bir genel müdüre (managing director) ve dışarıda da TRT Genel Müdürü İbrahim Eren'e bağlıdır (R. S. Ataş ile kişisel iletişim, 18 Temmuz 2017).

$\mathrm{Bu}$ durumda TRT World'un fonksiyonel organizasyon yapısına sahip olduğu anlaşılmaktadır. Kanalın yapılanmasında dikkat çeken departmanlar "vision”, "dijital” ve "creative"dir. Bu departmanların faaliyetleri ele alındığında kanalın küresel söylemine ve hedeflerine yönelik çalışmalar yürüttüğü ifade edilebilir. Yine kanalın küresel boyutta yayın yapabilmesi için dünyanın önemli merkezlerinde ofisleri bulunmaktadır. Bunların haricinde kanal, TRT bünyesindeki bazı merkezlerde de personel bulundurarak etkinlik alanını genişletmeye çalışmaktadır.

\section{Personel Politikası}

TRT World'un amaç ve hedefleri ile personel politikası doğrudan ilişkilidir ve kamu diplomasisi bağlamında TRT World'un konumunun tespit edilmesi açısından önemlidir. Bu çerçevede kanalın personel politikası tespiti edilmeye çalışılmıştır. Eren'in ifadelerine göre uluslararası yayıncılık yapmak amacıyla kurulan TRT World'un kuruluş aşamalarında, personel seçiminde profesyonel insan kaynakları şirketlerinden faydalanılmış ve büyük yayın kuruluşlarından transferler yapılmıştır. Ayrıca TRT'nin yayıncılık tecrübesi TRT World'un teknik 
altyapısının kurulmasını kolaylaştırmıștır. TRT World faaliyete geçtiği dönemde 500 kişilik ekiple çalışmaktaydı. Ayrıca TRT World'un teknik alt yapısı için gerekli personel TRT bünyesinden temin edilmiştir (Pala, 2015). Fatih Er TRT World'un personel seçimi sürecinde uluslararası ajanslardan faydalanılarak CV toplandığını, adayların mesleki yeterliliklerine ve İngilizce seviyelerine bakıldığını ve son olarak da istihdam edilen personellere PKK terör örgütü, FETÖ, Kıbrıs meselesi ve Ermeni sorunu gibi Türkiye'nin hassas olduğu konuların anlatıldığını ifade etmektedir (F. Er ile kişisel iletişim, 18 Temmuz 2017). Resul Serdar Ataş ise dünyanın her tarafından izlenebilmek için o ülkelere dair derinlikli bilgiler üretebilmenin gerektiğini, bu sebeple de personel envanterinde o ülkelerden profesyonellerin olması gerektiğini ve buralardan personellerin kanalda çalıştığını belirtmektedir (R. S. Ataş ile kişisel iletişim, 18 Temmuz 2017).

TRT World bünyesinde 31 farklı ülkeden gazeteciler çalışmaktadır. Bu ülkeler ağırlıklı olarak ana dili İngilizce olan ülkelerdir. Özellikle İngiltere ve Avustralya gibi ülkelerden daha fazla personel kanalda görev yapmaktadır (F. Er ile kişisel iletişim, 18 Temmuz 2017). Resul Serdar Ataş ise konuyla ilgili olarak "editoryal kadronun muhtemelen yarısına yakını şu anda Türk yarısına yakını da yabancı" ifadelerini kullanarak kanaldaki çalışanlara dair farklı bir istatistik vermektedir (R. S. Ataş ile kişisel iletişim, 18 Temmuz 2017).

TRT World kendi personelini yetiştirme noktasında adımlar atmaktadır. TRT World şu ana dek 214 genci -bunların \%95'i Türk, bunun da \%60’ı gurbetçi Türk- personel olarak envanterinde bulundurmakta ve bunların bir kısmını da yurtdışına farklı eğitimler için yollamaktadır. Kanal bu gençlerin bir kısmından da profesyonel anlamda verim almaya başlamıştır (F. Er ile kişisel iletişim, 18 Temmuz 2017). Konuyla ilgili olarak Fatih Er ile benzer ifadeler kullanan Resul Serdar Ataş ise “TRT World büyük oranda kendi yani Türkiye'nin insan kaynaklarına da güvenmek zorunda ve Türkiye'nin insan kaynaklarını yetiștirmek zorunda aynı zamanda. Bu insan kaynağını kendisinin oluşturması gerekiyor, uzun süre yani sürdürülebilirlik açısından" ifadeleriyle kanalın gençlere verdiği önemi belirtmektedir (R. S. Ataş ile kişisel iletişim, 18 Temmuz 2017).

TRT World'un yöneticileriyle yapılan görüşmeler ışığında kanalın belirli bir personel politikasının olduğu, bu politika dâhilinde dünyanın farklı ülkelerinden profesyonellerin istihdam edildiği, bu personellere Türkiye'nin kırmızı çizgilerinin ve bu bağlamda TRT World'un yayın politikasının anlatıldığı anlaşılmıştır. Bunun yanı sıra kanalın kendi personelini yetiştirmeye yönelik politikalarının olduğu anlaşılmış olup, dolayısıyla da ilerleyen yıllarda TRT World'un personel istihdamında Türkiye'nin insan gücünden daha fazla yararlanacağı ön görüsünde bulunulabilir.

\section{Hedef Kitlesi}

TRT World'un hedef kitlesinin öğrenilmesi, Türkiye'nin kamu diplomasisi stratejisi bağlamında bir uygunluğun olup olmadığının öğrenilmesi noktasında çalışma açısından önemli bir husustur. TRT World'un Türkiye'nin dünyaya açılan penceresi olma hedefiyle küre ölçeğindeki tüm izleyicilere ulaşmayı hedeflediği anlaşılmaktadır. Bu izleyicilerin İngilizce konuşan dünya ve İngilizce konuşan tüm insanlarla sınırlı olduğunu da belirtmek gerekmektedir. TRT World, Türkiye'nin dünyaya açılan penceresi olma hedefiyle tüm dünyadaki izleyicilere ulaşmayı hedeflemektedir. Kanalın yayın politikaları dâhilinde spesifik hedef kitlesi de söz konusudur. Fatih Er, 
TRT World'un hedef kitlesini yeni medya ve televizyon özelinde ikiye ayırdıklarını; bu bağlamda farklı izleyici gruplarının beklentilerini dikkat aldıklarını belirtmiştir (F. Er ile kişisel iletişim, 18 Temmuz 2017 ).

Daha çok yeni medya üzerindeki hedef kitleleri hakkında görüşlerini aktaran Fatih Er, farklı profiller oluşturup bunlara göre sosyal medya hesaplarında içeriklerini hazırladıklarını ifade etmiştir. Er, televizyon üzerinden ise daha çok beyaz yakalı diye ifade edilen kesime hitap etmeye çalıştıklarını belirtmiştir. Görüşme yapılan bir diğer TRT World yöneticisi Resul Serdar Ataş'ın hedef kitleye yönelik ifadeleri şu şekildedir (R. S. Ataş ile kişisel iletişim, 18 Temmuz 2017):

Ama göreceli olarak ben TRT World'un hedef kitlesinin genç bir hedef kitlesi olduğunu söyleyebilirim. Yani belki de TRT World'un kanal olarak hedef kitlesininyaş ortalamasının yaklaşı 25-45 arası iken ama dijitalde bu biraz daha düşer yani 18 yaşından itibaren olan bir hedef kitlesi var.

Kanalın hedef kitlesini kullanılan mecralara göre ayırması, hazırlanan içeriklerin ilgili hedef kitleye ulaşması açısından kayda değerdir. TRT World'un yeni medyada daha çok kişiyle etkileşime geçebilmek için profiller oluşturup, içeriklerini buna göre hazırlıyor olması kanala uzun vadede daha çok takipçi ve dolayısıyla etkileşim fırsatı sunabilmesi açısından önemlidir. TRT World genel itibariyle daha genç bir kesimi hedef kitle olarak görmektedir. Ayrıca kanalın yeni medyada ulaşmak istediği hedef kitlenin, televizyona oranla daha genç bir yaş grubundan başladığı anlaşılmaktadır. TRT World'un televizyon yayınlarıyla ulaşmak istediği hedef kitle ise ağırlıklı olarak beyaz yakalılardan -yöneticilerden Fatih Er'in ifadeleriyle "elitlerden"- ve 25-45 yaş grubundaki izleyicilerden oluşmaktadır. TRT World, habercilik anlayışı gereği sesi daha az duyulan bölgelerdeki insanların hikâyelerini İngilizce konuşan dünyaya anlatmak istemektedir.

\section{Konumlandırılması}

TRT World'un konumlandırmasına dair elde edilen verilerin değerlendirileceği bu başlıkta, kanalın diğer küresel haber kanallarıyla kıyaslandığında kendisini nerede gördüğ̈̈nün anlaşılması amaçlanmaktadır. Bu sayede TRT World'un diğer rakipleriyle kıyaslandığında nasıl bir pozisyona sahip olduğuna dair çıkarımlar yapılması mümkün olabilecektir. TRT World uluslararası yayıncılık yapması sebebiyle aynı kulvardaki diğer televizyon kuruluşlarıyla da rekabet halindedir. TRT World Haber Direktörü Fatih Er TRT World'u diğer uluslararası yayıncılık yapan kanallarla kıyasladıklarında Türkiye ve Orta Doğu'ya dair en doğru bilgi kaynağı olduğunu ve bu konuda El Cezire'yi kendilerine rakip gördüklerini ifade etmiştir. Er, bunun yanı sıra özellikle Osmanlı'nın kültürel mirası olan bölgelerde etkili olmak istediklerinin üzerinde durmuştur (F. Er ile kişisel iletişim, 18 Temmuz 2017). Resul Serdar Ataş ise TRT World'un insan kaynağı bakımından dünyada ilk bește yer aldığını ve Batı merkezli televizyon kuruluşlarına karşı kendilerini emperyal dili kıracak bir televizyon kanalı olarak gördüklerini ifade etmiştir (R. S. Ataş ile kişisel iletişim, 18 Temmuz 2017).

TRT World'un aynı bölgede bulunmaları bakımından kendisini ilk olarak El Cezire kanalıyla kıyaslaması, Osmanlı mirasının parçası olan bölgeler üzerinde El Cezire kanalının etkisi göz önüne alındığında Türkiye'nin kamu diplomasisi bağlamında önemli bir stratejidir. Bu açıdan bakılınca TRT World'un ilk olarak El Cezire ile rekabete girmesi beklenilen bir durumdur. Kanalın kuruluş amaçlarından 
birisi dünyada gerçekleşen olayları Türkiye'nin ve bu coğrafyanın nasıl değerlendireceğini anlama noktasında önemli bir başvuru kaynağı olmaktır. Bu noktada kanalın kendisini diğer küresel ağlardan farklı olarak haber stratejilerini bu bölgeler üzerine kurması ve bölgedeki bir diğer küresel haber kanalı El Cezire'ye rakip olması amaç ve hedefler ile konumlandırma arasında bir uyum olduğunun göstergesi olarak yorumlanabilir.

\section{Haber Stratejisi}

TRT World'un haberlerini üretirken nasıl bir stratejiye sahip olduğu ve bu stratejiyi hangi gerekçelerle belirledikleri çalışma açısından bir diğer öğrenilmek istenilen husustur. Haber stratejisi konusu uluslararası yayıncılık yapan kuruluşlar için oldukça önemlidir. Bu kuruluşların yayın politikaları siyasi, jeostratejik, sosyal, etnik, kültürel, dilsel ve ekonomik birçok etkene göre şekillenmektedir. Bunun yanı sıra yayın amaçları doğrultusunda yayın yapacakları coğrafyayı, dili ve içerikleri belirlemektedirler (Demirkıran, 2008, 321). TRT World'un haberlerinde temel olarak "insan" unsuru ön plana çıkartılmaktadır. Kanal haber stratejisini oluştururken kurum içerisinde bir uzlașıya sahiptir. Haberler önceden planlanarak yapılmaktadır (F. Er ile kişisel iletişim, 18 Temmuz 2017). Kanalın haber stratejisinin mazlumların sesini dünyaya duyurmak olduğu, dolayısıyla ana ekseninin de insan olduğu vurgulanmıştır. Bununla beraber kanalın prestijli bir dil kullanmasının gerekliliği üzerinde durulmuştur (R. S. Ataş ile kişisel iletişim, 18 Temmuz 2017 ).

Kamu diplomasisi ilişkiler inşa etme; diğer ülkelerin, kültürlerin ve insanların ihtiyaçlarını anlama; bakış açılarını aktarma; yanlış anlamaları düzeltme ve ortak meselelerin bulunabileceği yerleri arama ile ilgilidir (Leonard, Stead ve Smewing, 2012, 8-10). Bu açıdan değerlendirildiğinde TRT World'un sahip olduğu haber stratejisi ve unsuru ile uluslararası kamuoyunun nezdinde güvenilirliğini artırmaya yönelik olduğu; bu hedefin de planlanmış bir strateji çerçevesinde yürütülmeye çalışıldığı söylenebilir. Dolayısıyla kanalın Türkiye'nin argümanlarını dünyaya aktarmadaki etkisinin artacağını beklemek yanlış olmayacaktır. TRT World'un içerik üretim sürecinde temel kriterleri ve değerlerinin neler olduğuna dair yöneltilen soruya Fatih Er şu yanıtları vermiştir (F. Er ile kişisel iletişim, 18 Temmuz 2017):

\footnotetext{
Bizim için haberin içerisinde insan unsurunun olması yeterli. (...) Musul'da, Kuzey Irak'taki yaşanan krizi de insan üzerinden haberleştirdik. Batı'nın bu konuya ne kadar duyarsız olduğunu da yine insan hikâyeleri üzerinden haberleştirdik. Biz insan varsa haber olabileceğine inanıyoruz ve bunu dünyaya duyurmak için de elimizden gelen gayreti gösteriyoruz.
}

TRT World'un haber içeriği üretimi noktasındaki temel kriterlerini öğrenmek adına yöneltilen soru karşısında Resul Serdar Ataş’ın "Şam'daki bir ölüm kesinlikle Berlin'deki bir ölümden daha az değersiz değildir" ifadesi kanalın dünyada meydana gelen olaylar karşısında nasıl bir pozisyon alarak içeriklerini ürettiğini anlama noktasında önemli bir göstergedir (R. S. Ataş ile kişisel iletişim, 18 Temmuz 2017).

Kamu diplomasisi uygulamalarının başarılı olabilmesi için en temel nokta hedef kitleye gönderilen mesajlarda güvenilirliğinin olmasıdır. Eğer kamu diplomasisi uygulamalarında devletlerin salt çıkarları ön plana çıkar ve hedef kitle tarafından bu anlaşılırsa güvenilirlik azalmaktadır. Burada dikkat edilmesi gereken nokta uygulayıcıların kendi çıkarları için hedef kitlenin algılarını yönettiği izleniminin verilmemesidir (Ünver, 2016, 131-132). İşte bu noktada TRT World dünyanın 
her yerinde olan olaylara aynı mesafede davranan bir yayıncılık anlayışına sahip olduğunu ifade etmektedir. Diğer küresel yayıncılık yapan kuruluşların bu noktada adil bir bakıș açısına sahip olmadığı, TRT World'un ise onların aksine olaylara objektif bir şekilde yaklaştığı kanalın yöneticileri tarafından ifade edilmiştir. $\mathrm{Bu}$ anlayıș sayesinde gelecekte küresel izleyicinin gözünde kanalın daha tercih edilebilir olacağı söylenebilir. Bu da kanalın güvenilir bir dil kullanma ve güvenilir bir haber kaynağı olma amacına hizmet etmektedir.

TRT World'un sahip olduğu TRT altyapısı sayesinde dünyanın dört bir yanından kendi personeli ile haber içeriklerini elde edebilmektedir. Bunun dışında küresel haber ajanslarından alınan haberlerin ise İstanbul bürosunda tekrardan düzenlenmesi TRT World'un haberlere kendi bakış açısını yansıtabilmesi bakımından önemlidir (F. Er ile kişisel iletişim, 18 Temmuz 2017). Bu sayede kanal haber içeriklerine kendi haber unsurlarını dâhil ederek, olaylara yönelik bakış açısını hedef kitlesine aktarabilme fırsatını yakalamaktadır.

Haber sektörünün yeni medya ile birlikte neredeyse gerçek zamanlı ve multimedya içerikli bir yayıncılık yapmak zorunda kaldığı bir dönemde TRT World'un yeni medyaya yönelik anlayışını ve bu konudaki yeterliliğini öğrenmeye yönelik sorulan soruya kanal yöneticilerinden benzer cevaplar alınmıştır. Buna göre; kanalın "dijital" departmana sahip olması, bu alana yönelik çalışmaların yapıldığının göstergesi olarak kabul edilebilir. Ayrıca personelin yaş ortalamasının genç olması ve yeni iletişim teknolojilerine daha ilgili olmaları kanal için avantaj teşkil etmektedir. Ancak TRT World'un yeni bir kanal olması nedeniyle sosyal medyadaki takipçi sayıları diğer küresel haber kanallarının oldukça gerisindedir. Bu durum ise kanalın yeni medya üzerinde ne kadar kaliteli içerik oluşturursa oluştursun etkileşime geçeceği insan sayısının diğer küresel haber kanallarına oranla daha az olmasına neden olabilecektir. $\mathrm{Bu}$ da olumsuz bir durum olarak değerlendirilebilir. Ancak kanalın yeni medyaya yönelik planlamaları zamanla bu mecralarda daha geniş kitle ile etkileşime geçeceğinin göstergesi olarak değerlendirilebilir Fatih Er, yeni medyanın ilerleyen zamanlarda televizyonun önüne geçeceğini, bu yüzden TRT World'un da bu alana yoğunlaşarak gereken önemi verdiğini ifade etmiştir (F. Er ile kişisel iletişim, 18 Temmuz 2017).

İnternetin yaygınlaşmasıyla birlikte yeni medya uluslararası televizyon kuruluşları için de önemli bir hâl almıştır. İnternet aracılığıyla bireyler günün her anında her yerden haberlere ulaşabilmektedir. Bu nedenle uluslararası televizyon kuruluşları hedef kitleye ulaşabilmek için bu ortamdan yararlanmaktadırlar. TRT World de bu bağlamda gerek internet sitesi üzerinden gerekse de sosyal ağlar üzerinden eşzamanlı olarak yapılan canlı yayınlarla ve paylaşımlarla hedef kitlesine ulaşmayı hedeflemektedir. TRT World'un sosyal ağlar üzerinde içerik üretimi ve buradaki etkileșimlerle ilgili olarak kanalın iki yöneticisi de genel olarak başarılı olduklarına dair ifadeler kullanmışlardır. Fatih Er, dijital alanda ağırlıklı olarak yaşları 20 ile 25 arasındaki Türk gençlerin çalıştığını ve bunun gelecek adına önemli olduğunu belirtmiştir. Ancak tecrübesi az olan bu gençlerin şu an için online içerik üretimi ve dağıtımı noktasında biraz yavaş kalabildiğini ama üretilen içeriklerin kalitesi bakımından rakiplerine kıyasla bir eksiklerinin olmadığını vurgulamıştır (F. Er ile kişisel iletişim, 18 Temmuz 2017). 
Yapılan görüşmelerde ve yayın sürecini takip ederek edindiğimiz izlenimde kanalın yeni medya ekibinin genç olması ve TRT World'un yöneticilerinden Fatih Er'in de ifade ettiği gibi bu genç ekibin genel itibariyle habercilik deneyimini az olmasından hareketle kanalın yeni medya içeriklerinin oluşturulma sürecini yavaşlattığ tespiti yapılabilir. Nitekim sosyal medya içerikleri takip edildiğinde genel olarak "breaking news" dışında kalan haberlerin yeteri kadar hızlı oluşturulup yeni medyada paylaşılamadığı gözlemlenmiştir. $\mathrm{Bu}$ da arama motorlarında İngilizce olarak sıcağı sıcağına haber arayanların TRT World'e ilk kaynak olarak ulaşmasını zorlaştırmaktadır. Bu durum ise kanal yöneticilerinin belirttiği amaçlara ulaşılmasını güçleştirdiği tespitini yapmamıza imkân vermektedir.

\section{TV Programları}

Uluslararası yayıncılık yapan bir televizyon kanalı olarak TRT World'un yayın akışında hangi TV programlarının yer aldığı ve bunların hangi konulara yoğunlaştığı kanalın amaçları-hedefleri ile ilgili bir tutarlılığın olup olmaması noktasında tespitler yapılmasına olanak tanıyabilecektir. TRT World kanalının haftalık yayın akışı incelendiğinde düzenli olarak yayınlanan 12 farklı program ile izleyiciye ulaştığ görülmektedir. Bu programların yanı sıra gündeme dair özel belgesel programları da izleyiciye sunulmaktadır. Programlara ait kısa bilgiler aşağıdaki gibidir (TRT World, 2017b):

Strait Talk: Dünyayı etkileyen gelişmeler hakkında değerlendirmelerin yapıldığı ve alanında uzman kişilerle gerçekleştirilen röportajlarla meselelerin derinlemesine ele alındığı bir programdır. Program Ali Mustafa tarafından kanalın İstanbul stüdyolarında sunulmaktadır.

News: Program dünyada olup biten en son haberleri ekrana getirmektedir.

Showcase: Dünyanın farklı ülkelerinde gerçekleşen kültür sanat etkinliklerinin izleyiciyle buluştuğu bir programdır.

The Newsmaker: Hayatımızı şekillendiren insanları ve hikâyeleri derinlemesine inceleyen programdır. Dünyanın her köşesinden hazırlanan özel haberlerin yayınlandığı programdır.

Playback: Program TRT World'un önceki hafta yapmış olduğu en iyi orijinal hikâyeleri ve röportajları göstermektedir.

Money Talks: Derin analiz ve raporlarla herkesin kendi finansal dünyasını yönetmesine yardımcı olmayı amaçlayan bir programdır.

Roundtable: Dünyaca ünlü haber sunucusu ve muhabir olan David Foster'ın sunduğu programda dünyadaki güncel meselelere dair yuvarlak bir masa etrafında toplanan uzmanların yüz yüze gerçekleștirdikleri tartışmaları ekrana getirmektedir. Program kanalın Londra stüdyolarında yapılmaktadır.

Scitech Voyager: Bilim gazetecisi Jheni Osman'ın sunduğu program bilim dünyasındaki gelişmeleri ekrana getirmektedir.

Beyond the Game: Büyük etkinlikleri ekrana getiren, önemli kişilerle konuşan ve önemli olayların arkasındaki hikâyeleri inceleyen bir spor programıdır. 
Route 66: Çeşitli konu başlıkları altında ABD’nin toplumsal yapısını irdeleyen belgesel niteliğinde bir programdır.

Nexus: TRT World'un Londra stüdyosunda hazırlanan program, uluslararası televizyon kuruluşlarında çalışmış gazeteci Matthew Moore sunmaktadır. Kasım ayının sonunda yayınlanmaya başlayan programda şu ana kadar Donald Trump, Vladimir Putin gibi siyasi liderlerin yanı sıra Mark Zuckerberg gibi dünyanın en güçlü insanları çeşitli açılardan ele alınmaktadır.

Kanalın yakın zamanda izleyicisiyle buluşan bir diğer program ise "Bigger Than Five"dır. Bu programda Türkiye'nin küresel söylemlerinden biri olan "dünya beșten büyüktür" anlayışıyla Birleşmiş Milletler'den Trump’a, IŞíD’den göç meselesine kadar dünya gündemini meşgul eden konular irdelenmektedir. Bu programların yanı sıra "Focal Point" ve "Off The Grid" adlı iki farklı program haftalık yayın akışları içerisinde yer almasalar da zaman zaman ekrana gelmektedir. Bu programlarda belirli konular hakkında belgesel niteliğinde özel içerikler hazırlanmaktadır. Bu programların yanı sıra TRT World yeni programlar için hazırlıklar yapmaktadır. İlk olarak Evliya Çelebi'nin gittiği yerlere tekrar uğrayıp, onun seyahatnamesinde kaleme aldığı yerlerin o zamanki hali ile şu anki hali arasındaki durumu gösteren bir program tasarlanmaktadır (Yıldızalp ve İleri, 2017). TRT World'un programları arasında özellikle dünyaca ünlü gazeteciler tarafından sunulan Strait Talk, The Newsmaker, Roundtable ve Nexus gibi programlarla önemli bir haber kanalı olarak izleyicileri tarafından tercih edilebilir olmaya çalıştığı ifade edilebilir. Bunun yanı sıra TRT World'un Route 66 gibi (ABD toplumuna yönelik bir program) Türkiye'nin yumuşak gücünü kullanabileceği bölgelere yönelik haftalık yayınlanacak programlara ihtiyacı olduğu söylenebilir.

\section{Dağıtım Ağı}

Tüm küreye yayın yapmak amacıyla kurulan TRT World'un bu amaca uygun bir şekilde dünyanın her yanındaki izleyiciye ulaşabileceği bir dağıtım ağına sahip olması beklenmektedir. Bu sayede yayın politikası ve kuruluş amaçları-hedefleri dâhilinde belirlemiş olduğu haber stratejileriyle üretilen içerikleri dünyaya servis edebilme imkânı yakalayacaktır. TRT World kuruluşunun üzerine geçen 2 yılın ardından dağıtım ağı belirli bir genişliğe ulaşmıştır. Hem çeşitli uydular üzerinden izlenebilmesi hem de farklı platformlar sayesinde geniş çapta izleyicisiyle buluşuyor olması kanalın dağıtım ağındaki hızlı gelişmeyi göstermektedir.

İbrahim Eren, dünyanın her ülkesinde TV izleme alışkanlıklarının aynı olmadığını, Türkiye'de TV izleyicilerinin \%90'ının uydu yayınlarını takip ettiğini ancak bu oranın dünyanın her yerinde aynı olmadığını belirtmektedir. Bazı ülkelerde uydu yayınlarından ziyade platformlar ve kablolu yayınların tercih edildiğini vurgulayan Eren, bu duruma örnek olarak TRT World'un İngiltere'de Sky platformuna sokulmasını göstermektedir (Yıldızalp ve İleri, 2017). TRT World 1 Mart 2017 tarihi itibariyle dünyanın önde gelen uluslararası medya şirketlerinden beIN Media'da yayınlanmaktadır. TRT World bu platform üzerinden HD olarak izleyicilere sunulmaktadır (TVBEurope, 2017). Ayrıca Doğu Avrupa ve Bağımsız Devletler Topluluğu (BDT) ülkelerinin en büyük online video ve TV kanalları izleme platformu Megogo ile yaptığı anlaşma ile aylık 40 milyonluk bir seyirci kitlesine ulaşma imkanına erişmektedir (TRT Haber, 2017b). TRT World son olarak Pay TV servis sağlayıcısı olan Foxtel ile yapılan çoklu platform anlaşmasıyla kablolu 
yayın, uydu ve geniş bant üzerinden Avustralya'daki izleyicilerle buluşabilecektir (Ho, 2017).

Fatih Er, TRT World'un dağıtım konusunda planlanandan daha önde olduklarını belirterek şu ifadeler kullanmıştır:

2017 sonuna kadar dünyanın birçok noktasında belli yerlerde yayına girmemizin olmuş olması gerekiyordu ama biz ikinci yarıya geçtiğimizde bunun çok büyük bir kısmını tamamladık. Amerika Birleșik Devletleri'nden İngiltere'deki kablolu televizyonlara kadar hepsinde varız. (...). 'Distribution' konusunda da inşallah en kısa zamanda hedefimizin çok daha üzerinde olacă̆ız.

TRT World Haber Koordinatörü Fatih Er'in ifadelerinden yola çlkarak, kanalın kuruluş aşamasında 2017 yılı için belirlenmiş bir dağıtım hedefinin olduğu, bu hedef dâhilinde istenilen noktanın da ötesine gidildiği anlaşılmaktadır. Kanal yöneticisi her ne kadar dağıtım ağı konusunda hedeflenenden daha ileri bir duruma geldiklerini ifade etse de dağıtım ağını gösteren haritadan da yola çıkarak daha alınması gereken çok yol olduğu söylenebilir.

\section{Resmi Web Sayfası}

Geleneksel medyanın yanı sıra yeni iletişim teknolojilerinin sunduğu imkânlara ortaya çıkan ve yeni bir medya türü olarak tasnif edilen yeni medya da geleneksel medya kuruluşları için izleyicilerine/okuyucularına/dinleyicilerine ulaşmak için önemli bir araç ve mecra konumundadır. Bu teknolojik gelişmeler medya kuruluşları için web sayfalarının kullanımını bir gereklilik haline getirmiştir. Web sayfalarının hem maliyetinin düşük olması hem de erişilebilirliğinin kolay olması gibi özellikleri medya kuruluşlarına, hedef kitlelerine ulaşmada büyük imkânlar sunmaktadır. TRT World'un takipçilerine web sayfası üzerinden ürettiği içerikleri güncel bir şekilde hem metin ve görsel olarak hem de videolar ve canlı yayınlarla sunuyor olması kanalın bu mecraya önem verdiğini gösteren bir durumdur. Zaman içerisinde web sayfasında yapılan yeniliklerle beraber görseller değerlendirildiğinde TRT World'un web sayfasının tasarım ve estetik açısından yenilendiği, kullanım kolaylığının arttırıldığı söylenebilir (TRT World, 2018).

\section{Sosyal Medya Hesapları}

Sosyal medya uluslararası yayıncılık yapan medya kuruluşlarına hedef kitle ile daha kolay etkileşime geçebilme kolaylığı sağlaması açısından son derece önemlidir. $\mathrm{Bu}$ sebeple TRT World'un çeşitli sosyal medya hesapları da çalışma açısından dikkate alınmıştır. TRT World takipçi/beğenen sayılarının çokluğuna göre sırasıyla Facebook, Twitter, Youtube ve Instagram üzerinde resmi hesaplara sahiptir. 6 Ocak 2018 tarihi itibariyle TRT World kanalının Facebook takipçi sayısı 1,052,559 kişi (TRT World Facebook, 2018), Twitter takipçi sayısı 122,843 (TRT World Twitter, 2018), Youtube takipçi sayısı 105,251 (TRT World Youtube, 2018) ve Instagram takipçi sayısı 16,364'tür (TRT World Instagram, 2018). Bu durum ise TRT World'un sosyal medyada takipçi sayısını arttırması için çalışmalar yapmasına bir işaret olarak değerlendirilebilir.

\section{Sonuç}

KDK'nin ortaya koyduğu misyon, vizyon ve hedef olarak belirlediği ilkeler Türkiye'nin kamu diplomasisi stratejisinin ana unsurlarının çerçevesini belirlememize olanak tanımaktadır. Türkiye sahip olduğu demokrasisi ve yumuşak gücüne kaynaklık eden 
Balkanlar'dan Türkistan'a, İslam dünyasına uzanan tarihsel ve kültürel derinliği sayesinde etki sahasını genişletmeyi hedeflemektedir. Bu bağlamda, Türk kamu diplomasisi stratejisinin ana unsurları şu şekilde belirlenmiştir:

- Türkiye'nin kamu diplomasisi stratejisi Osmanlı'nın eski toprakları üzerinde yaşayan devletler ile onların halkları için bir cazibe merkezi olmak,

- Türkiye'nin izlediği politikaları rasyonel, ikna edici ve savunulabilir bir şekilde dünya kamuoyuna anlatmak.

Türkiye'nin kamu diplomasisi stratejisini uygulamada yürütülen faaliyetler içinde ilgili kurum ve kuruluşlara farklı görevler düşmektedir. TRT, AA ve BYEGM, Türkiye'nin kamu diplomasisi faaliyetlerinde uluslararası yayıncılık noktasında değerlendirilmektedir. Özellikle TRT bünyesinde yer alan uluslararası yayıncılık faaliyeti yapan televizyon kanalları önemli birer kamu diplomasisi aracıdır. Ancak TRT bünyesindeki bu kanallar ya Türkçe yayınlarla yurtdışında yaşayan Türk vatandaşlarını hedef almakta ya da çeşitli dillerde yayınlar yapan kanallarıyla bölgesel olarak izleyicilerine ulaşmaktadır. TRT bünyesinde tüm küreye hitap edecek ve dünyanın her tarafında geçerli olan İngilizce yayın yapacak bir kanalın olmaması farklı akademisyenler tarafından kamu diplomasisi açısından zafiyet olarak değerlendirilmekteydi.

TRT World'un Türkiye'nin kamu diplomasisi faaliyetlerinin unsurlarından biri olan uluslararası yayıncılık boyutunun önemli bir aktörü olarak Türkiye'nin kamu diplomasi stratejisi çerçevesinde konumlandırıldığı ortaya çıkmaktadır. Bu amaçla faaliyetler yürüten TRT'nin TRT World'den önce bünyesinde bulunan kanallar arasından TRT Avaz, TRT Kurdîve TRT-El Arabia'nın uluslararası yayıncılık faaliyetleri bölgesel hedef kitleye yönelik ve onların dillerinde yapılmaktadır. TRT World ise İngilizce olarak yaptığı yayınlarla Türkiye'nin dünyaya açılan penceresi olma iddiası ve hedefiyle çalışmalarını yürütmektedir. TRT World dünyada gerçekleşen olayları Türkiye'nin bakış açısıyla değerlendirip dünya gündemini bu doğrultuda oluşturmayı amaçlamaktadır. Ayrıca özellikle Türkiye ve Türkiye'yi ilgilendiren her türlü meselede ilk aranılan kaynak olmak (gerek televizyonda gerekse de internet ortamlarında) için yaptığı çalışmaların, Türk kamu diplomasisine ilerleyen zamanlarda kayda değer bir katkı sağlaması beklenmektedir. TRT World'un hedeflediği doğrultuda ilerlemesi, kanalın etki gücünü artıracağı ve dolayısıyla Türkiye’nin yumuşak gücünü artırarak kamu diplomasisini güçlendireceği öngörüsünde bulunulabilir. Özellikle KDK'nın Türk kamu diplomasisini Türkiye'nin hikayesini etkin bir şekilde dünya kamuoyuna aktarmak olarak tanımladığı düşünüldügü̈nde TRT World'un kuruluş amacının KDK'nın temel kuruluş amacıyla paralellik taşıdığı anlaşılmaktadır.

Bu çalışma kapsamında yararlanılan çoklu veri kaynaklarından ve özellikle görüşme yapılan TRT World yöneticilerinin ifadelerinden yola çıkarak kanalın kuruluş tarihi olan 2015 yılından beri televizyon programlarının sayılarını artırması, dağıtım ağını genişletmesi, kendi personelini yetiştirmeye yönelik projelerinden verim almaya başlaması bakımından TRT World'un kuruluş günü itibariyle ilerleme kat ettiği söylenebilir. Ancak kanalın başta bütçe olmak üzere bazı konularda rekabet halinde olduğu diğer uluslararası yayın kuruluşlarından geride olması görünürdeki önemli dezavantajların bașında gelmektedir.

TRT World Haber Direktörü Fatih Er'in de çalışmanın ilgili başlığında belirttiği gibi düzenli ve hızlı güncelleme noktasında eksiklikler söz konusudur. Bu durum ise 
kanalın kendisine belirlediği hedeflerden biri olan arama motorlarında Türkiye'ye dair yapılan aramalarda ilk kaynak olması amacını olumsuz olarak etkilemektedir. TRT World'un hedefleri ve tespit edilen strateji dikkate alındığında sosyal medya kullanımının daha hızlı, güncel ve efektif olması gerektiği sonucu ortaya çıkmaktadır. Kamu diplomasisi faaliyeti yapan BBC ve DW, resmi internet sayfalarında kendi ülkelerinin dilini öğretmeye yönelik içerikler bulundurmaktadırlar. Bir kültürün en önemli aktarıcısı ve taşıyıcısı olan dilin öğretilmesi, Türkiye'nin yumuşak gücünü artırması açısından oldukça faydalı olacaktır. Bu amaçla TRT World'un resmi internet sayfasında Türkçe'nin öğretilmesine yönelik kaliteli içerikler oluşturması oldukça önemlidir.

Yapılan bu detaylı çalışmanın neticesinde ise monografik bir inceleme (kuruluş süreci, amaç ve hedefleri, bütçesi, organizasyonel yapısı, personel politikası, hedef kitlesi, konumlandırılması, haber stratejisi, TV programları, resmi web sayfası ve sosyal medya hesapları) ile TRT World'un tüm dünyaya İngilizce yayın yaparak Türkiye'nin kamu diplomasisi stratejisinin unsurlarından birisi olduğu ve Türkiye'nin uluslararası yayıncılık çabalarının tamamlayıcı bir aktörü olduğu sonucuna varılmıştır.

Bu çalışmada elde edilen önemli sonuçlardan bir tanesi de kanalın haber içeriklerini yoğunlukla İstanbul'da ürettiği ve küresel haber kanallarının egemen söylemlerinin dışına çıkmaya çalıştığıdır. Bu konuların üzerine çeşitli akademik araştırmaların yapılması ve bu durumun gerçeği ne derecede yansıttığının ortaya konulması daha kapsamlı ve detaylı araştırmaların konusu olabilecek bir durumdur. Televizyon programlarının içeriklerinin, haber içeriklerinin ve bunların hedef kitle üzerindeki etkilerinin daha sonra yapılacak akademik çalışmalarla ortaya konulması hem kamu diplomasisi ve medya ilişkisi açısından hem de Türkiye'deki medya çalışmaları açısından önemli bir katkı olacaktır.

Ayrıca bu çalışmanın yapıldığı dönemde varlıklarını sürdüren KDK, BYEGM gibi kamu kurumlarının Cumhurbaşkanlığı İletişim Başkanlığı'nın kurulmasıyla yeni bir kurumsal yapılanmanın parçası haline getirilmesi sürecinin de yeni çalışmaları gerekli kıldığı açıktır. Bu çerçevede bu çalışmanın; Cumhurbaşkanlığı Hükümet Sistemi ile birlikte kamunun yeniden yapılandırılması sürecini kapsayacak şekilde Türkiye'nin kamu diplomasisi stratejilerinin oluşturulmasında ve yürütülmesinde stratejik iletişim ve kamu diplomasisi, kamu diplomasisi ve medya gibi konularda yapılacak yeni çalışmalara kaynaklık edebileceği değerlendirilmektedir.

\section{Notlar}

${ }^{1} 0$ tarihte TRT Genel Müdür Yardımcısı olarak programa katılmıştır.

\section{Kaynakça}

Aydeniz, H. (2015), Türkiye'de Medya ve İletişim Çalışmalarına İlişkin Bir Çerçeve ve Yeni Yönelimler. L.Sunar (Ed.). Sosyal Bilimlerde Yeni Eğilimler (s. 251-287). Ankara: Nobel Akademik Yayıncılık.

Aydınlı, E., Kurubaş, E. ve Özdemir, H. (2015). Yöntem, Kuram, Komplo. İstanbul: Küre Yayınları.

Bektaş, A. (2013). Kamuoyu, İletişim ve Demokrasi (4. Baskı). İstanbul: Bağlam Yayınları. 
Budak, A. (2014). Osmanlı Modernleşmesi Gazetecilik ve Edebiyat. İstanbul: Bilge Kültür Sanat.

Canbey, M. (2017). Türkiye’de Kamu Diplomasisi Bağlamında Kamu Yayıncılığının Rolü: TRT ve Anadolu Ajansı. Doktora tezi, İstanbul Üniversitesi, İstanbul.

Demirkıran, C. (2008). Uluslararası Televizyon Yayıncılığının Tarihsel Gelişim Süreci: Fransa TV5 MONDE ile Türkiye TRT-INT ve TRT TÜRK Karşılaştırmalı İncelemesi. Doktora tezi, İstanbul Üniversitesi, İstanbul.

Devlet Planlama Teşkilatı (2000). Erişim: 26 Ekim 2016, Sekizinci Beș Yıllık Kalkınma Planı: http://www.kalkinma.gov.tr/Lists/Kalknma\%20Planlar/ Attachments/2/plan8.pdf

Devran, Y. (2015). Yeni Türkiye'nin Küresel Sesi TRT World: Fırsatlar ve Güçlükler. E-Journal of Intermedia, 2(2), 281-294.

DiCicco-Bloom, B. ve Crabtree, B. F. (2006). The Qualitative Research Interview. Medical Education, 40(4), 314-321.

Ekşi, M. (2014). Kamu Diplomasisi ve Ak Parti Dönemi Türk Dış Politikası. Ankara: Siyasal Kitabevi.

Ertekin, B. A. (2012). UluslararasıSistemde Görsel-İşitsel Medyanın Kamu Diplomasisi ve Kamuoyu Yaratmadaki Önemi: Trt'nin Türkçe Dışında Yayın Yapan Kanalları Üzerine Bir İnceleme. Elektronik Sosyal Bilimler Dergisi, 11(42), 323-354.

Erzen, M. Ü. (2014). Kamu Diplomasisi (2. Baskı). İstanbul: Derin Yayınları.

Gilboa, E. (2005). The CNN effect: The Search for A Communication Theory of International Relations. Political Communication, 22(1), 27-45.

Güler, A., Halıcıoğlu, M. B. ve Taşğın, S. (2015). Sosyal Bilimlerde Nitel Araştırma (2 Baskı). Ankara: Seçkin Yayıncılık.

Güngör, N. (2013). İletişim: Kuramlar ve Yaklaşımlar (2. Baskı). Ankara: Siyasal Kitabevi.

Ho, R. (2017). TRT World Expands Global Reach With Foxtel. Erişim: 20 Aralık 2017, Television Asia: https://tva.onscreenasia.com/2017/09/trt-world-expandsglobal-reach-foxtel/

İnceoğlu, Y. G. (2015). Uluslararası Medya. İstanbul: Der Yayınları.

Kalın, İ. (2011). Soft Power and Public Diplomacy in Turkey. Perception Journal of International Affairs, 16(3), 5-23.

Kalın, İ. (2017). Türk Dış Politikası ve Kamu Diplomasisi. Erişim: 22 Aralık 2017, T.C. Başbakanlık Kamu Diplomasisi Koordinatörlüğü: https://kdk.gov.tr/sag/turkdis-politikasi-ve-kamu-diplomasisi/20

Kaptan, S. (1998). Bilimsel Araştırma ve İstatistik Teknikleri (11 Baskı). Ankara: Tekışık Web Ofset Tesisleri.

Karadağ, H. (2016). Uluslararası İlişkilerde Yeni Bir Boyut. Ankara: Nobel Akademik Yayıncilık.

KDK (2017). KDK Hedefler. Erişim: 22 Aralık 2017: https://kdk.gov.tr/kurumsal/ hedefler $/ 9$ 
Leonard, M., Stead, C. ve Smewing, C. (2002). Public Diplomacy. Londra: The Foreign Policy Centre.

Nye, J. (2004). Soft Power. New York: Public Affairs.

Nye, J. (2008). Public Diplomacy and Soft Power. The Annals of the American Academy of Political and Social Science, 616(1), 94-109.

Özkan, A. (2014). Role of Public Diplomacy in Establishing Nation Branding and Public Diplomacy Possibilities of Turkey. International Association of Social Science Research, ISSN: 2147-6284. Special Issue: International Relations, 1-5.

Özkan, A. (2017). Medyanın Kamu Diplomasisi Rolü. Erişim: 25 Haziran 2017, Kamu Diplomasisi Enstitüsü: http://www.kamudiplomasisi.org/makaleler/ makaleler/99-medyann-kamu-diplomasisi-rolue\%20

Pala, Ç. (2015) TRT WORLD'un Temel İlkesi 'Ínsan' Olacak. Erişim: 7 Ağustos 2017, Anadolu Ajansı: http://aa.com.tr/tr/turkiye/trtworldun-temel-ilkesi-insanolacak-/457936

Robinson, P. (2002). The CNN Effect: The Myth of News, Foreign Policy and Intervention. New York: Routledge.

Sancar, G. A. (2015). Kamu Diplomasisinde Medyanın Önemi: Anadolu Ajansı Örneği. M. Şahin ve B. S. Çevik (Ed.) Türk Dış Politikası ve Kamu Diplomasisi (s. 439464). İstanbul: Nobel Akademik Yayıncllık.

Satow, E. (1966). A Guide to Diplomatic Practice. London: Longmans.

Seib, P. (2008). The Al Jazeera Effect. Washington: Potomac Books.

Silcock, B. W. (2002). Global News, National Stories: Producers as Mythmakers at Germany's Deutsche Welle Television. Journalism \& Mass Communication Quarterly, 79(2), 339-352.

Snow, N. (2009). Rethinking Public Diplomacy. N. Snow ve P. M. Taylor (Ed.). Routledge Handbook of Public Diplomacy (s. 3-11). New York: Routledge.

TRT Haber (2016). TRT World'den Görkemli Açılış Erişim: 20 Aralık 2017, http:// www.trthaber.com/haber/yasam/trt-worldden-gorkemli-acilis-284284. html

TRT Haber (2017a). TRT World, Sesini Duyuramayanların Sesi Olmak Üzere Kuruldu. Erişim: 20 Aralık 2017: http://www.trthaber.com/haber/gundem/trt-worldsesini-duyuramayanlarin-sesi-olmak-uzere-kuruldu-338410.html

TRT Haber (2017b). TRT World, Megogo'dan Seyredilebilecek. Erişim: 2 Ekim 2017: http://www.trthaber.com/haber/turkiye/trt-world-megogodanseyredilebilecek-306375.html

TRT World (2017a). TRT World About Us, Erişim: 20 Eylül 2017: http://www. trtworld.com/about

TRT World (2017b). TRT World TV Schedule. Erişim: 20 Eylül 2017: https://www. trtworld.com/tv-schedule

TRT World (2018). Erişim: 6 Ocak 2018: https://www.trtworld.com/ 
TRT World Research Center (2017). TRT World Forum Day 1: Opening Keynote Speech. Erişim: 25 Ekim 2017: https://www.youtube.com/ watch?v=hPm2Xhyuf_E\&list=PLurQXM093sg9Crn70Im56RtynAbl15r5p\& index $=2$

TRT World Facebook (2018). Erişim: 6 Ocak 2018: https://www.facebook.com/ trtworld/

TRT World Instagram (2018). Erişim: 6 Ocak 2018: https://www.instagram.com/ trtworld $/$ ?hl=tr

TRT World Twitter (2018). Erişim: 6 Ocak 2018: https://twitter.com/trtworld

TRT World Youtube (2018). Erişim: 6 Ocak 2018: https://www.youtube.com/ channel/UC7fWeaHhqgM4Ry-RMpM2YYw

TVBEurope (2017). TRT World Launches on BeIN. Erişim: 29 Eylül 2017: http:// www.tvbeurope.com/trt-world-launches-bein/

Ünver, O. C. (2016). Kamu Diplomasisi ve Türkiye. Ü. Özdağ ve Y. Demirağ (Ed.). Türk Dış Politikası (s. 125-146). Ankara: Kripto.

Versan, R. (1995). Tarih Boyunca ve Günümüzde Diplomasi. İstanbul Üniversitesi Siyasal Bilgiler Fakültesi Dergisi (10), 89-96.

Yanardağoğlu, E. (2014). Uluslararası İletişim ve Kamu Diplomasisi: BBC Dünya Servisi Haber Merkezi Örneği. İletişim Kuram ve Araștırma Dergisi (38), 115131.

Yıldırım, G. (2015). Uluslararası Halkla İlişkiler Perspektifinden Kamu Diplomasisi. İstanbul: Beta Basım.

Yıldızalp, M. ve İleri, E. (2017). TRT World Dünyanın Her Yerinden İzlenebilecek. Erişim: 2 Ekim 2017, Anadolu Ajansı: http://aa.com.tr/tr/turkiye/trt-worlddunyanin-her-yerinden-izlenebilecek/768176

Zabun, B. (2007). Ankara Fen Lisesi Monografisi (1964-2004). Doktora tezi, Gazi Üniversitesi, Ankara. 
